International Journal of Trend in Scientific Research and Development (IJTSRD)

Volume: 3 | Issue: 3 | Mar-Apr 2019 Available Online: www.ijtsrd.com e-ISSN: 2456 - 6470

\title{
Investigation on Mechanical Properties of TIG Welded Joint and its Efficiency
}

\author{
Mr. I. S. N. V. R. Prashanth'1, K. Lavanya², Meherkeziah², P. Navya² \\ ${ }^{1}$ Assistant Professor, ${ }^{2}$ UG Scholar \\ 1,2Department of Mechanical Engineering, Guru Nanak Institute of Technology, Rangareddy, Telangana, India
}

How to cite this paper: Mr. I. S. N. V. R. Prashanth | K. Lavanya | Meherkeziah | P. Navya "Investigation on Mechanical Properties of TIG Welded Joint and its Efficiency" Published in International Journal of Trend in Scientific Research and Development (ijtsrd), ISSN: 24566470, Volume-3 | Issue-3, April 2019, pp.1194-1196, URL: https://www.ijtsrd.c om/papers/ijtsrd23 244.pdf

Copyright (C) 2019 by author(s) and International Journal of Trend in Scientific Research and Development Journal. This is an Open Access article distributed under the terms of the Creative Commons Attribution License (CC BY 4.0) (http://creativeco mmons.org/license s/by/4.0)

\section{INTRODUCTION}

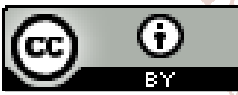

Welding is a fabrication process that materials, usually metals or thermoplastics, by causing fusion. In addition to melting the base metal, a filler material is typically added to the joint to form a pool of molten material (weld pool) that cools to form a joint that is usually stronger than the base material. Pressure may also be used in conjunction with heat, or by itself, to produce a weld. The factors affecting the welded joint strength is mainly based on type of joint, joint strength, no of joints to the joined, moisture presented in air and atmospheric conditions.

The mild steel joining process is easy when compared to other conventional metallic materials and mild steel is advantageous material and its coefficient of expansion is finite.[1].

\section{LITERATURE REVIEW}

\subsection{Tungsten Insert Gas (TIG) Welding:}

In TIG welding method, the arc is strucked between small gap of non-consumption in tungsten electrode and the work piece in a shield of inert gases (Argon, Helium). Figure 1, represents the TIG welding processes.

Filler material is applied for matching the similar work pieces. Generally, DC arc is used with tungsten as the negative pole (DCEN). The excessive heat is generated at the tungsten electrode if this is used as anode.

Ahmetdurgutlu et.al [2] Investigation the effect of hydrogen in argon as shielding gas for TIG welding of 316L austenitic stainless steel. They used current 115A welding speed $100 \mathrm{~mm} / \mathrm{min}$ and gas flow rate $101 / \mathrm{min}$ for welding of $4 \mathrm{~mm}$ thick plate. For all shielding media, hardness of weld metal is lower than that of HAZ and base metal. Penetration depth, weld bead width and mean grain size in the weld metal increase with increasing hydrogen content, The highest tensile strength was obtained for the sample welded under shielding gas of $1.5 \% \mathrm{H}-\mathrm{Ar}$.

Ahmed Khalid Hussain et.al [3] Investigating the effect of welding speed on tensile strength of the welded joint by TIG welding process of mild steel of $4 \mathrm{~mm}$ thickness. The strength of the welded joint was tested by a universal tensile testing machine. Welding was done on specimen of single $\mathrm{V}$ butt joint with welding speed of $1800-7200 \mathrm{~mm} / \mathrm{mi}$. From the experimental results it was revealed that strength of the weld zone is less than base metal tensile strength increases with reduction of welding speed. 
International Journal of Trend in Scientific Research and Development (IJTSRD) @ www.ijtsrd.com eISSN: 2456-6470

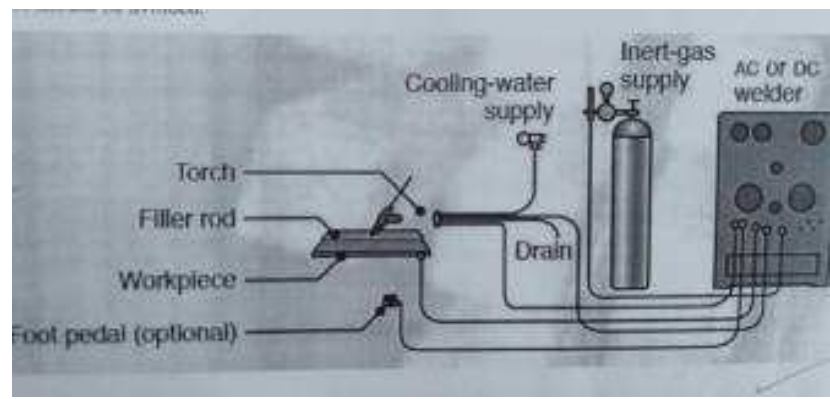

\section{MATERIALS AND METHODOLOGY}

The extended form of IS 2062 mild steel is consider for the present work. It was the thickness of $6 \mathrm{~mm}$ and width of $20 \mathrm{~mm}$. The physical and mechanical properties of IS 2062 is represented in table 1.

Fig 1: TIG welding testing apparatus.

Table 1: Physical and mechanical properties of IS 2062 steel.

\begin{tabular}{|c|c|c|c|c|c|c|}
\hline Element & $\begin{array}{c}\text { Tensile } \\
\text { Strength in } \\
\text { Mpa }\end{array}$ & $\begin{array}{c}\text { Yield Stress } \\
(<20 \mathbf{m m})\end{array}$ & $\begin{array}{c}\text { Yield Stress } \\
(\mathbf{2 0 - 4 0} \mathbf{~ m m})\end{array}$ & $\begin{array}{c}\text { Yield Stress } \\
(>\mathbf{4 0} \mathbf{~ m m})\end{array}$ & $\begin{array}{c}\text { \% Elongation at } \\
\text { gauge length 5.65 S0 }\end{array}$ & $\begin{array}{c}\text { Bend Test } \\
(\mathbf{m i n})\end{array}$ \\
\hline $\begin{array}{c}\text { Carbon Steel } \\
\text { IS2062 }\end{array}$ & 410 & 250 & 240 & 230 & $23 \mathrm{~min}$ & $\begin{array}{c}3 \mathrm{t}^{*}\left(\mathrm{t}^{*} \text { is } 3 \text { times }\right. \\
\text { thickness })\end{array}$ \\
\hline
\end{tabular}

In this investigation leeb hardness test of Dry Penetrant Test (DPT), radiography, bending and tensile tests has been done as welded joints by TIG welding. The joined mild steel work pieces are shown in figure 2.

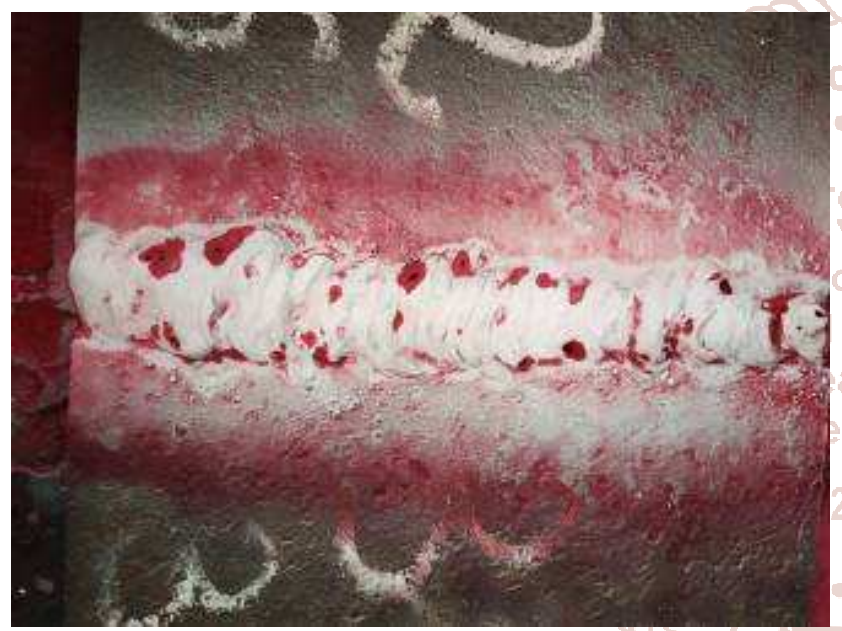

Fig 2: DTP tested specimen.

\section{RESULTS AND DISCUSSION}

In this investigation leeb hardness testing has been done on leeb hard ness test machine is shown in figure 3.

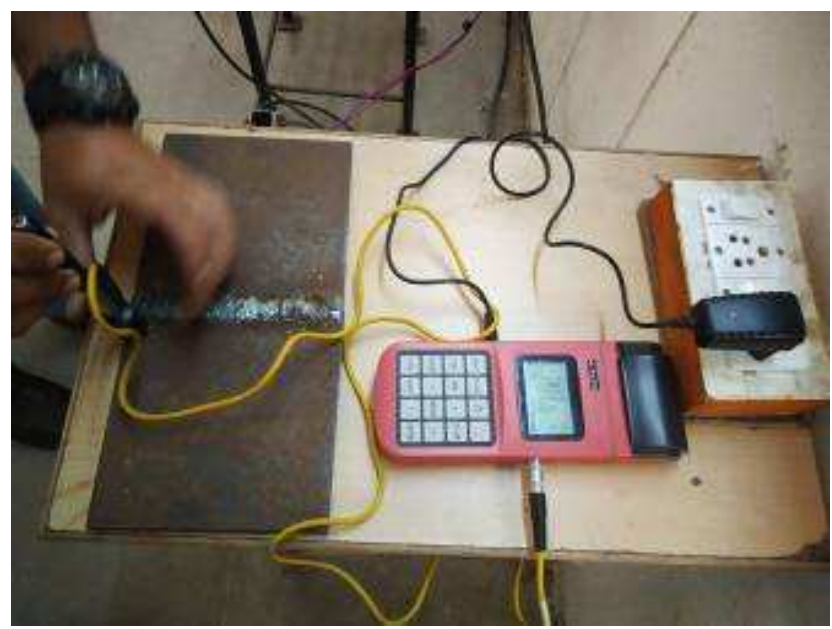

Fig 3: Leeb hardness testing machine.

And the value of hard ness in welded region is represented in the following in table 2 .
Table2: Hardness test of welded joint. Type of welding $\quad$ Hardness of weld region (HRB) \begin{tabular}{l|r} 
TIG & 45 \\
\hline
\end{tabular}

Different types of tensile properties of welded mild steel IS 2062 were illustrated such asyield strength, ultimate tensile strength, and percentage elongation. For each condition 5 specimens were tested and average properties of welded joints are considered for the investigation. The above said properties are shown in following table 3.

Table3: Mechanical properties of welded joint.

\begin{tabular}{|l|c|c|c|}
\hline $\begin{array}{c}\text { Type of } \\
\text { joint }\end{array}$ & $\begin{array}{c}\text { Yield } \\
\text { Strength } \\
(\mathrm{MPa})\end{array}$ & $\begin{array}{c}\text { Ultimate } \\
\text { Tensile } \\
\text { Strength (MPa) }\end{array}$ & $\begin{array}{c}\text { Elongation } \\
(\%)\end{array}$ \\
\hline aाTIG & 83.3 & 144.80 & 21 \\
\hline
\end{tabular}

This steady also intended to know the welded joint failures by using non-destructive tests (DPT \& radiography tests). The liquid penetrate welded zone is clearly represented in the figure 4. Also values of liquid penetrates test were represented in table 4

Table 4: LPT preparation values for MS sheet.

\begin{tabular}{|c|c|c|c|}
\hline Time & Minimum & Maximum & Temperature \\
\hline Dwell Time & 5 & 10 & 28 \\
\hline $\begin{array}{c}\text { Developing } \\
\text { Time }\end{array}$ & 2 & 5 & 28 \\
\hline Drying Time & - & - & - \\
\hline Emulsification & - & - & - \\
\hline
\end{tabular}

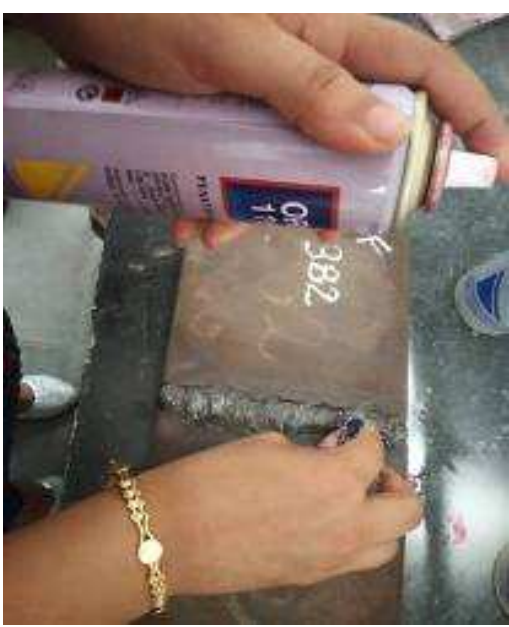

Fig 4: LPT testing for MS sheet. 
One of the radiography tested welded zone sample is represented in table 5 and it is observed in figure5.

Table 5: Radiography observation values for MS sheet.

\begin{tabular}{|c|c|c|c|}
\hline & TIME & TEMPERTURE & SOLUTION \\
\hline DEVELOPER & $5 \mathrm{Min}$ & $22 \mathrm{C}$ & - \\
\hline STOP BATH & $5 \mathrm{Min}$ & $22 \mathrm{C}$ & - \\
\hline FIXER & $5 \mathrm{Min}$ & $22 \mathrm{C}$ & - \\
\hline RINSING WATER & $5 \mathrm{Min}$ & $22 \mathrm{C}$ & - \\
\hline $\begin{array}{c}\text { WEETING AGENT } \\
\text { DRYING }\end{array}$ & $5 \mathrm{Min}$ & $22 \mathrm{C}$ & - \\
\hline
\end{tabular}

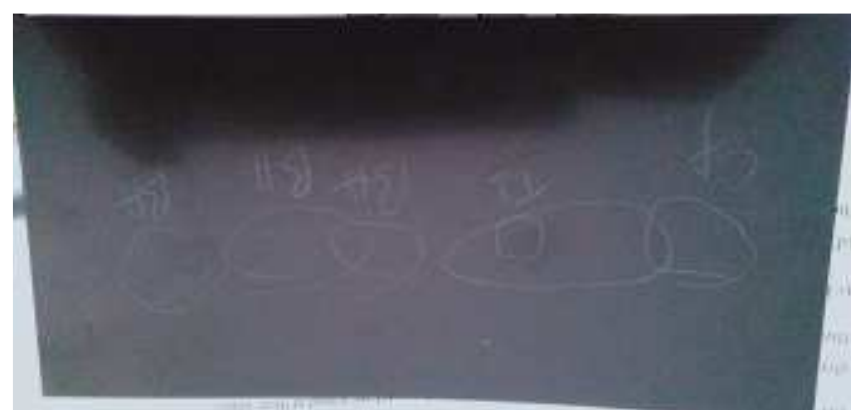

Fig 5: Radiography defected zones for welded MS sheet zones.

\section{CONCLUSION}

1. The joining of the two mild steel plates is done successfully IS 2062 rolled steel plates by using TIG welding process. Here the join of the metal used for the joint of butt joint. After the completion of the joining of the plates the work piece is subjected to the nondestructive testing of the inspection methods where the
TIG welding, leeb hardness test, dye penetrant testing, bending test, tensile test.

2. In the dye penetrant testing the defects found was incomplete fusion on the face side and lack of the penetration on the root side. On subjected the work piece of for leeb hardness test machine inspection was improper root and face penetration. Excess face penetration undercut and welded breed profile were encountered.

3. While using leeb hardness test the hardness of the metal is found at different positions i.e., at base metal, heat affected zone, weld pool at top middle and bottom positions. In the tensile test where the work piece is pulled from the sides to know the elongation to be $23 \%$, yield load to be $103.950 \mathrm{KN}$. On performing the bend test the load corresponding value of the deflection on both the sides of the specimen were checked and found the maximum load for which the failure of the specimen will not occur is $12.5 \mathrm{KN}$.

4. After performing all these test on the work piece it can be concluded that the joint is good in the performance.

\section{REFERENCES}

[1] Pattern, W.J. "The science and practice of welding. $4^{\text {th }}$ ed. "Prentice-Hall, Inc. Englewood Cliffs, New Jersey, pp.111,1967.

[2] http://www.azom.com/article.aspx ?ArticleID=1446

[3] www.micomm.co.za/portfolio/alfa

[4] en.wikipedia.org/wiki/GTAW

[5] www.weldwell.co.nz/site/weldwell 